\title{
Immunocytochemical Analysis of Cells in the Pars tuberalis of the Rat Hypophysis with Antisera to Hormones of the Pars distalis *
}

\author{
Burton L. Baker and Ya-Yen Yu \\ Department of Anatomy and The Reproductive Endocrinology Program, \\ The University of Michigan Medical School, Ann Arbor, Michigan, USA
}

Received November 12, 1974

\begin{abstract}
Summary. The objective was to acquire evidence regarding the secretory capacity of cells in the pars tuberalis of the rat pituitary by the application of immunocytochemical staining. For this purpose the conjugated antibody and immunoglobulin-enzyme bridge techniques were utilized with antisera to the following hormones of the pars distalis: human somatotropin, human thyrotropin, human $\beta$-melanotropin, ovine luteinizing hormone (LH), porcine $\beta^{17-39}$-corticotropin, and $\beta^{1-24}$-corticotropin. Only LH-containing cells were demonstrated. They were exceedingly rare in the cephalic pars tuberalis beneath the median eminence. The frequency of LH-cells was greater in the pars tuberalis associated with the infundibulum and increased distally. LH-cells were most common ventrolateral to the infundibular stem and occurred singly and in clusters. These results indicate that following hypophysectomy the portion of the pars tuberalis that remains in situ has the capacity to secrete only LH of all the pars distalis hormones.
\end{abstract}

Key words: Pituitary gland - Cytology - Pars tuberalis - Immunocytochemistry Luteinizing hormone.

\section{Introduction}

The physiologic role of the hypophyseal pars tuberalis is almost totally unknown. Investigation of this problem is needed because, as pointed out by numerous previous investigators, much of the pars tuberalis remains in the body after hypophysectomy and might compensate for loss of pituitary hormones. Furthermore, adherence of the pars tuberalis to the median eminence could explain why extracts of the hypothalamus have been found to contain activities characteristic of certain hormones secreted by the pars distalis. Thus, a substance possessing thyroid-stimulating activity is reported to be released by cultured guinea pig hypothalamus (Petrovic and Porte, 1963) and to occur in the stalk-median eminence area of the rat (Bakke and Lawrence, 1967). Also, corticotropic activity appears to exist in the hypothalamus of the beef (McCann and Haberland, 1959; Royce and Sayers, 1958, 1960), dog (Schally et al., 1962), hog (Guillemin et al., 1962), and rat (Mialhe-Voloss et al., 1968). Luteinizing hormone (LH) (Guillemin et al., 1963) and follicle-stimulating hormone (Courrier et al., 1963) are present in extracts of sheep hypothalamus and LH occurs in extracts of rat median eminence--pituitary stalk (Gay et al., 1970). Although

Send offprint requests to: Dr. Burton L. Baker, Department of Anatomy Medical Science Building II, University of Michigan, Ann Arbor, Michigan 48104, USA.

* Supported in part by NIH research grants HD 03159-07 and HD-08333. 
in some of these studies an attempt was made to eliminate the pars tuberalis as a factor, in others the pars tuberalis was excised together with the hypothalamus and could have contributed hormones to the extract. In regard to secretion of hormones by the pars tuberalis following hypophysectomy, Lostroh (1963) found that the testes of some hypophysectomized rats do not involute and attributed this result to production of gonadotropin by cells associated with the infundibular stalk above the diaphragma sellae.

The recent development of immunocytochemical procedures and their extensive application to the study of pituitary hormones provide a ready means for evaluating the secretory potential of the pars tuberalis. In this study we report the results of our attempts to demonstrate in the rat pars tuberalis the presence of cells competent to secrete hormones with immunologic properties like the hormones of the pars distalis.

\section{Material and Methods}

Twenty female and 17 male, young adult Sprague-Dawley rats were maintained in airconditioned quarters with a lighting schedule of $14 \mathrm{hr}$ light and $10 \mathrm{hr}$ darkness/day. They were killed by decapitation and the hypothalamic-hypophysial complex was fixed by immersion in Bouin's fluid. After being embedded in Tissuemat, the area was sectioned serially at 3 or $5 \mu$ on either a sagittal or transverse plane. Regularly spaced sections in the series were stained with cresyl violet to permit selection of the most desirable areas for analysis of the pars tuberalis.

Sections representing all regions of the pars tuberalis in each animal were "stained" immunocytochemically. Thus for a specimen cut in a transverse plane, sections of the pars tuberalis were prepared at the cephalic end of the median eminence, the broadest part of the median eminence, the origin of the infundibulum, the upper region of the infundibular stem, and near the junction of the stem with the hypophysis. Generally employed for immunocytachemistry was the conjugated antibody method of Nakane and Pierce (1967); for some animals this procedure was supplemented with the immunoglobulin-enzyme bridge technique of Mason et al. (1969) because theoretically the latter method provides greater sensitivity. Sections containing pars tuberalis were treated for detection of hormones found in the pars distalis by using antisera to $\mathrm{h}$-somatotropin ${ }^{1}, \mathrm{r}$-prolactin, $\beta^{1-24}$ - and $\mathrm{p}-\beta^{17-39}$-corticotropins, $\mathrm{h}$-thyrotropin, o-luteinizing hormone and $\mathrm{h}$-melanotropin. Prior publications from this laboratory supporting the specificity of these antisera for demonstrating specific cells of the rat pars distalis are as follows: somatotropin and prolactin, Baker et al. (1969); corticotropin and melanotropin, Baker et al. (1970), Baker and Drummond (1972); thyrotropin, Baker and $\mathrm{Yu}(1971 \mathrm{a}, \mathrm{b})$; and luteinizing hormone, Baker et al. (1972).

The following steps were taken to control the observations. In order to verify the effectiveness of the procedure for the pars distalis, a control slide bearing a section of the hypo-

1 A small letter preceding the name of a hormone indicates the species of origin: $h$, human; $r$, rat; o, ovine; $p$, porcine.

Fig. 1. Transverse sections through median eminence, infundibular stem, and pars tuberalis of adult female rat arranged in cephalo-caudal order $(a-e)$; stained immunocytochemically for LH-cells. In all photographs interrupted line marks boundary between pars tuberalis and median eminence or infundibular stem. $\times 137$. (a) and (b) LH-cells absent from pars tuberalis in tuberoinfundibular sulcus and in its broad expanse beneath median eminence. (c) In this section of infundibular stem LH-cells are absent from all of pars tuberalis including that on dorsolateral side beneath caudal end of tuberoinfundibular sulcus. (d) LH-cells clustered in pars tuberalis on one side of stem. (e) Near junction of stem and hypophysis, LH-cells lie singly and in a group in pars tuberalis. In Fig. $1 \mathrm{~d}$ and e erythrocytes by virtue of their endogenous peroxidase should not be confused with LH-cells 

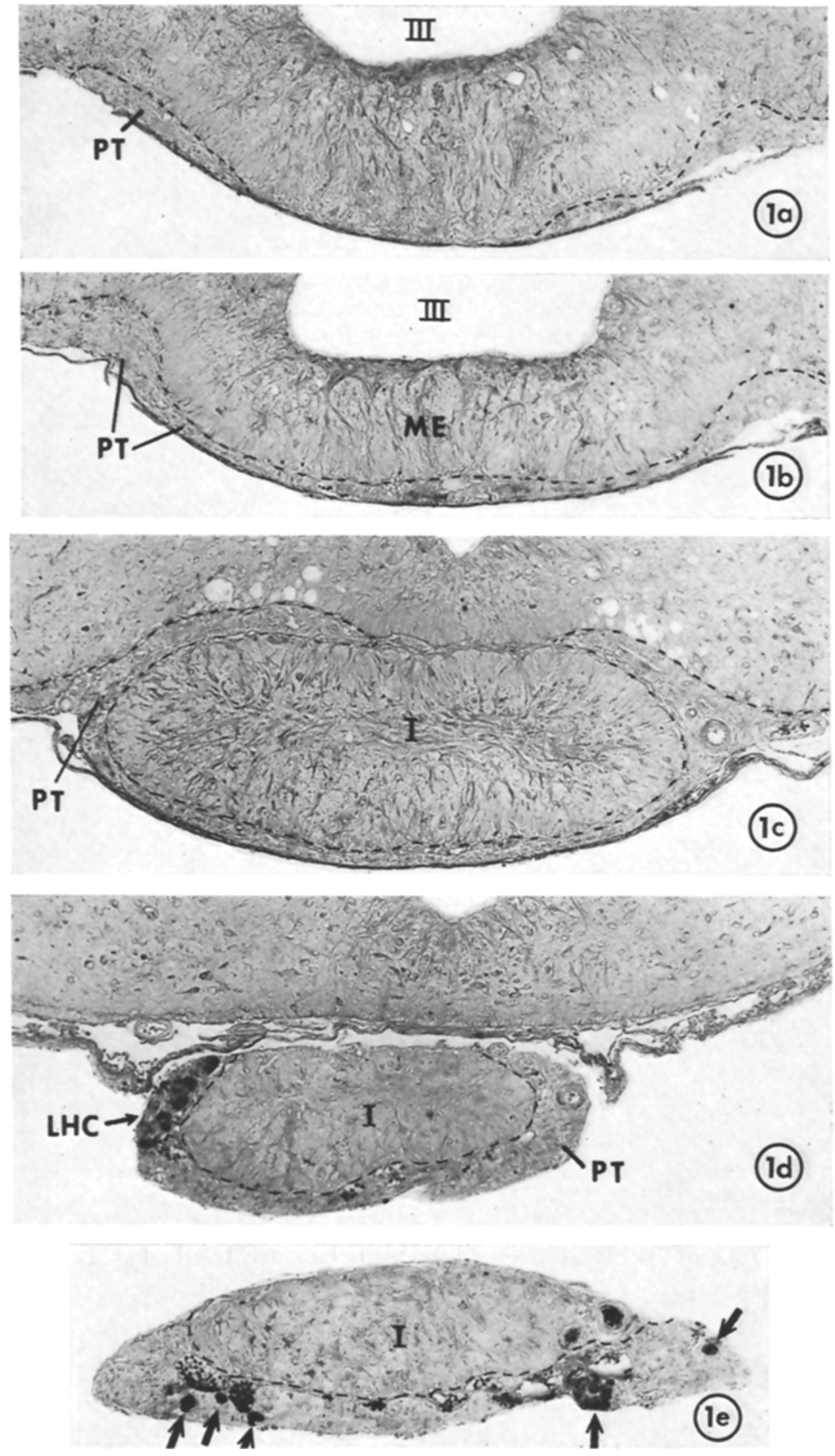


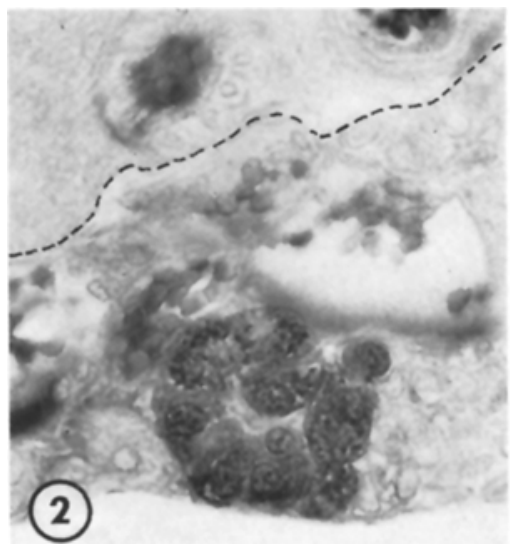

Fig. 2

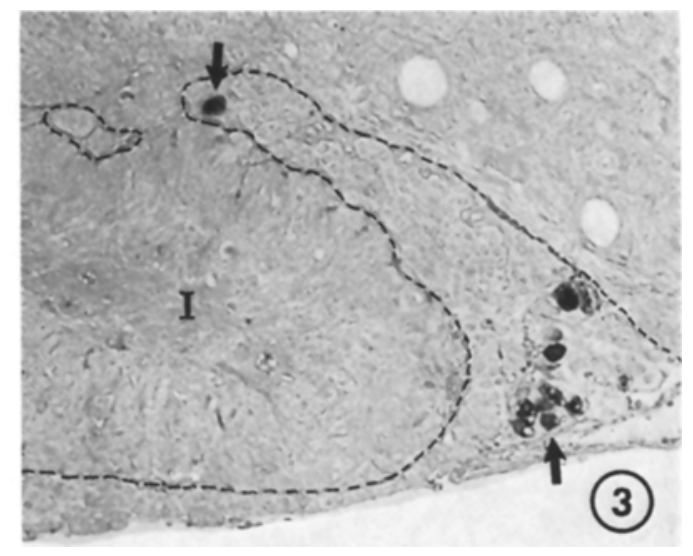

Fig. 3

Fig. 2. Enlargement of LH-cell cluster on right side in Fig. 1 e. $\times 600$

Fig. 3. One side of infundibular stem showing LH-cells in lateral pars tuberalis and one cell (arrow) in dorsal extension toward tuberoinfundibular sulcus. $\times 130$

physis was always included with a group of slides representing the pars tuberalis. Also, with antiserum which permitted staining of cells in the pars tuberalis, additional specificity controls included sections prepared with the immunocytochemical procedure but with (a) normal rabbit serum substituted for the specific hormone antiserum or (b) prior absorption of the specific antiserum with the hormonal antigen. In both types of controls no staining was obtained.

\section{Results}

For description, the pars tuberalis will be subdivided into two regions, i.e., a cephalic portion that is attached to the ventral surface of the median eminence, and a caudal part that partially envelops the proximal portion of the infundibulum and covers the ventral and ventrolateral surfaces of the infundibular stem.

No staining was obtained in the cephalic pars tuberalis (Fig. 1a, 1 b) with any of the antisera available with the exception of individual LH-cells ${ }^{2}$, or small clusters of them, in two of 20 females and two of 17 males. Thus in this portion of the pars tuberalis their incidence was irregular and may be insignificant. LH-cells were constantly present in the caudal pars tuberalis (Fig. 1d, 1e) with their relative number increasing as the hypophysis was approached. LH-cells occurred in groups alongside portal vessels on the ventral and ventrolateral sides of the infundibular stem (Fig. 2). Although usually absent (Fig. 1c), LH-cells sometimes appeared in the portion of the pars tuberalis that lies in the caudal part of the lateral tuberoinfundibular sulci (Fig. 3). Although making up a small proportion of the total parenchymal cell population, LH-cells were demonstrated in the pars tuberalis of all males and all females but one. No significant differences in LH-cells could be detected between males and females.

2 Since the functional role of parenchymal cells in the pars tuberalis is not known, they will be designated by the name of the hormone they contain, e.g., "luteinizing hormone or LHcells," rather than by the terms applied to specialized cells of the pars distalis. 
Apart from corticotrophs, which sometimes extended for a very short distance into the most caudal part of the pars tuberalis, no cells were identified in the pars tuberalis that contained somatotropin, thyrotropin, melanotropin or prolactin.

\section{Discussion}

Our demonstration with immunocytochemistry that LH-cells occur in the caudal portion of the rat pars tuberalis confirms the inferences drawn by several investigators who utilized other experimental procedures. Thus, PAS-positive basophils, considered to be gonadotropic cells, were observed in this region by Legait et al. (1970), Klein et al. (1970), and Stoeckel et al. (1973); further, their presence has been revealed with electron microscopy (Dellmann et al., 1974).

In view of the rather small number of LH-cells, it follows that our study has not thrown light on the secretory activity of the great majority of parenchymal cells that compose the remainder of the pars tuberalis. As observed in the rat with the light microscope, most cells appear chromophobic while a smaller number are cyanophilic, periodic-acid-Schiff (PAS)-positive, or erythrosinophilic (Legait et al., 1970; Klein et al., 1970). With electron microscopy a large group of parenchymal cells possess no secretory granules (Oota and Kurosumi, 1966), most of these being designated "follicular cells" (Dellmann et al., 1974) because they tend to encompass a cavity. However, a secretory role is clearly indicated for other cells that contain dense granules measuring 100-150 $\mathrm{m} \mu$ in diameter (Klein et al., 1970; Stutinsky et al., 1964; Rinne, 1966; Stoeckel et al., 1973). Indeed, Klein et al. (1970) suggested the probability that the granulated cells produce corticotropin or thyrotropin, this idea being based primarily on similarity in diameter of their cytoplasmic granules to those in the corticotroph and thyrotroph of the pars distalis. Our inability under carefully controlled conditions to demonstrate the presence of corticotropin or thyrotropin in these cells with immunocytochemistry makes this possibility highly unlikely.

Finally, two instructive generalizations may be drawn from our observations. First, the apparent absence of thyrotropin, corticotropin, melanotropin, somatotropin and prolactin from the pars tuberalis indicates that when such activities appear in hypothalamic extracts the source must be cells other than those in the pars tuberalis. Second, following hypophysectomy, the only one of the hormones studied that might be secreted into the circulation by the pars tuberalis is a gonadotropin. If during pituitary ablation the pituitary stalk is severed close to the median eminence, few LH-cells will remain to do this. Although Stutinsky et al. (1964) have described proliferation of gonadotrophs (FSH-cells) and corticotrophs in the pars tuberalis after hypophysectomy, more definitive analysis of the remaining tuberal cells is needed.

\section{References}

Baker, B. L., Drummond, Sister T.: The cellular origins of corticotropin and melanotropin as revealed by immunochemical staining. Amer. J. Anat. 134, 395-410 (1972)

Baker, B. L., Midgley, A. R., Jr., Gersten, B. E., Yu, Y.-Y.: Differentiation of growth hormone- and prolactin-containing acidophils with peroxidase-labeled antibody. Anat. Rec. 164, 163-172 (1969) 
Baker, B. L., Pek, S., Midgley, A. R., Jr., Gersten, B. E.: Identification of the corticotropin cell in rat hypophyses with peroxidase-labeled antibody. Anat. Rec. 166, 557-568 (1970)

Baker, B. L., Pierce, J. G., Cornell, J. S.: The utility of antiserums to subunits of TSH and LH for immunochemical staining of the rat hypophysis. Amer. J. Anat. 135, 251-268 $(1972)$

Baker, B. L., Yu, Y.-Y.: The thyrotropic cell of the rat hypophysis as studied with peroxidase-labeled antibody. Amer. J. Anat. 131, 55-72 (1971 a)

Baker, B. L., Yu, Y.-Y.: Hypophyseal changes induced by thyroid deficiency and thyroxine administration as revealed by immunochemical staining. Endocrinology 89, 996-1004 $(1971 \mathrm{~b})$

Bakke, J. L., Lawrence, N.: Thyrotropin (TSH) in the rat stalk-median eminence. Neuroendocrinology 2, 315-325 (1967)

Courrier, R., Colonge, A., Sakiz, E., Guillemin, R., Jutisz, M. : Présence dans un extrait salin d'hypothalamus d'une activité folliculo-stimulante de type FSH. C.R. Acad. Sci. (Paris) 257, 1206-1210 (1963)

Dellmann, H.-D., Stoeckel, M. E., Hindelang-Gertner, C., Porte, A., Stutinsky, F.: A comparative ultrastructural study of the pars tuberalis of various mammals, the chicken and the newt. Cell Tiss. Res. 148, 313-329 (1974)

Gay, V. L., Niswender, G. D., Midgley, A. R., Jr.: Response of individual rats and sheep to one or more injections of hypothalamic extract as determined by radioimmunoassay of plasma LH. Endocrinology 86, 1305-1312 (1970)

Guillemin, R., Jutisz, M., Sakiz, E.: Purification partielle d'un facteur hypothalamique (LRF) stimulant la sécrétion de l'hormone hypophysaire de lutéinisation (LH). C.R. Acad. Sci. (Paris) 256, 504-507 (1963)

Guillemin, R., Schally, A. V., Lipscomb, H. S., Andersen, R., Long, J. M.: On the presence in hog hypothalamus of $\beta$-corticotropin releasing factor, $\alpha$ - and $\beta$-melanocyte stimulating hormones, adrenocorticotropin, lysine-vasopressin and oxytocin. Endocrinology 70, 471-477 (1962)

Klein, M.-J., Stoeckel, M.-E., Porte, A., Stutinsky, F.: Arguments ultrastructuraux en faveur de l'existence de cellules corticotropes (à ACTH) dans la pars intermedia et dans la pars tuberalis de l'hypophyse du rat. C.R. Acad. Sci. (Paris), Sér. D 271, 2159-2162 (1970)

Legait, H., Legait, E., Roux, M. : Etude morphologique et expérimentale sur la pars tuberalis de l'hypophyse de quelques mammifères. C.R. Ass. Anat. 54, 261-265 (1970)

Lostroh, A. J.: Effect of follicle-stimulating hormone and interstitial cell-stimulating hormone on spermatogenesis in Long-Evans rats hypophysectomized for six months. Acta endocr. (Kbh.) 43, 592-600 (1963)

Mason, T. E., Phifer, R. F., Spicer, S. S., Swallow, R. A., Dreskin, R. B.: An immunoglobulin-enzyme bridge method for localizing tissue antigens. J. Histochem. Cytochem. 17, 563-569 (1969)

McCann, S. M., Haberland, P.: Relative abundance of vasopressin and corticotrophinreleasing factor in neurohypophysial extracts. Proc. Soc. exp. Biol. (N.Y.) 102, 319-325 (1959)

Mialhe-Voloss, C., Anan, C., Koch, B., Lutz, B.: Variations des activités "CRF" et corticotrope de l'hypothalamus après hypophysectomie chez le rat. Arch. Anat. Histol. Embryol. Norm. Exp. 51, 457-463 (1968)

Nakane, P. K., Pierce, G. B., Jr.: Enzyme-labeled antibodies for the light and electron microscopic localization of tissue antigens. J. Cell Biol. 33, 307-318 (1967)

Oota, Y., Kurosumi, K.: Electron microscopic studies on the pars tuberalis of the rat hypophysis. Arch. Histol. Jap. 27, 501-520 (1966)

Petrovic, A., Porte, A.: Nouvelles données sur l'activité thyréostimulante en culture organotypique de fragments d'hypothalamus de Cobaye adulte normal. C.R. Soc. Biol. (Paris) 157, 1051-1054 (1963)

Rinne, U. K.: Ultrastructure of the median eminence of the rat. Z. Zellforsch. 74, 98-122 (1966)

Royce, P. C., Sayers, G.: Corticotropin releasing activity of a pepsin labile factor in the hypothalamus. Proc. Soc. exp. Biol. (N.Y.) 98, 677-680 (1958) 
Royce, P. C., Sayers, G.: Purification of hypothalamic corticotropin releasing hormone. Proc. Soc. exp. Biol. (N.Y.) 103, 447-450 (1960)

Schally, A. V., Lipscomb, H. S., Long, J. M., Dear, W. E., Guillemin, R.: Chromatography and hormonal activities of dog hypothalamus. Endocrinology 70, 478-480 (1962)

Stoeckel, M. E., Hindelang-Gertner, C., Porte, A., Dellmann, H.-D., Stutinsky, F.: Sur les caractères cytologiques spécifiques de la pars tuberalis de l'hypophyse et sa différenciation précoce chez le foetus de rat. C.R. Acad. Sci. (Paris), Sár. D 277, 97-100 (1973)

Stutinsky, F., Porte, A., Stoeckel, M.-E.: Sur les modifications ultrastructurales de la pars tuberalis du Rat après hypophysectomie. C.R. Acad. Sei. (Paris) 259, 1765-1767 (1964) 